\title{
FAIR VALUE MEASUREMENT DISCLOSURES: PARTICULARITIES IN THE CONTEXT OF LISTED COMPANIES AND EUROPEAN FUNDING
}

\author{
Dumitru Matiş ${ }^{1}$ \\ Maria Ionela Damian ${ }^{2}$ \\ Carmen Giorgiana Bonaci ${ }^{3}$
}

\begin{abstract}
In the last years and especially after the outbreak of the recent financial and economic crisis, fair value and implicitly fair value measurements for financial statements have been harshly criticized, mainly by the representatives of the companies activating in the financial sector. Therefore, the aim of this paper is to study the issue of disclosures on fair value measurements in the financial statements by firstly sketching a guide of best practices and further focusing on empirically documenting potential determinants. In order to achieve the objective of our study, the employed methodology draws on similar studies in research literature, calculating for each company included in the study a disclosure score called disclosure index and then using a statistical program to run a multivariate linear regression. The obtained results document, among other, that the entity size positively affects the fair value measurements disclosure index. Particularities regarding fair value measurement related disclosures are discussed in the context of European funding (subsidies). Our study therefore contributes (through the developed empirical study) to the literature on the determinants of companies' disclosure practices in the particular area of fair value measurements.
\end{abstract}

Key words: fair value, valuation, financial statements, disclosure index, determinants, European funding (subsidies).

JEL codes: $M 40$, M41

\section{Introduction}

In accounting, there are few topics that generate more debates than valuation rules because they directly affect the accounting figures used in investment decisions, assessing responsibility of managers to shareholders (i.e. stewardship) or management of entity's resources. Of course, the fair value - as the standard of value - does not deny this assertion, especially given that the recent brought the issue even more into the spotlight. The debate about the usefulness of fair value accounting was also enhanced in the context of the financial and economic crisis blockage in 20072009. Opponents of fair value accounting have insisted that financial statements based on fair value measurements accelerated the financial crisis and significantly enhanced its impact on affected companies (Hughes and Tett, 2008; King, 2009; Veron, 2008). Thus, fair value accounting has been the target of critics who came especially from the banking sector.

1 Babeş-Bolyai University, Cluj-Napoca, Romania, e-mail: dumitru.matis@econ.ubbcluj.ro 2 Babeş-Bolyai University, Cluj-Napoca Romania, e-mail: damian_maria_ionela@yahoo.com

3 Babeş-Bolyai University, Cluj-Napoca Romania, e-mail: carmen.bonaci@econ.ubbcluj.ro 
In this paper we study the issue of disclosures on fair value measurements in financial reporting by focusing on the potential determinants. We addressed this issue because, given all the criticism brought to fair value during the recent economic and financial crisis, we wondered if it is possible that the fault in many cases would be the lack of appropriate information for the users of accounting information. Accounting disclosure and determinants analysis has always been a major issue in accounting as documented throughout trade literature. Ding et al. (2004) synthesize such studies by distinguishing between researchers trying to answer two major questions: (1) What attitude do firms take towards accounting disclosure, either general or specific (e.g. social responsibility, disclosure on business segments, environmental protects, R\&D activities, etc.)? (2) Why do some firms disclose more (or less) than others? The first research question is known as disclosure level evaluation and the second one as disclosure determinants analysis (Ding et al., 2004). In our study we attempted to answer to the second question.

We therefore selected 20 publicly traded companies from the financial sector. A total of 10 companies were selected from the constituents of the London Stock Exchange index FTSE 100. The other 10 companies were selected from the constituents of the Frankfurt Stock Exchange DAX and MDAX indices. We analyzed these companies' financial statements for the years 2007, 2008 and 2009. Afterwards we used a well-known method in the literature which consists on calculating for each company included in the study a disclosure score called disclosure index and then using a statistical program to run a multivariate linear regression, with the index as dependent variable, and a set characteristics (financial or nonfinancial) of the related firm (the size of the company, the type of entity's financial statements auditor, sector of activity or the country in which is located) as independent variables. Based on the performed regressions we determined that the entity size positively affects the fair value measurements disclosure index.

\section{Literature review}

Ding et al. (2004) cover studies such as Healy and Palepu (2001), and also a discussion by Core (2001), providing an overview of the empirical disclosure literature (Ding et al., 2004). They therefore document many researchers analyzing the corporate characteristics that could help forecast the disclosure level of a firm (Ding et al., 2004). Moreover, it seems like the fact is that many firms exceed the disclosure requirements by providing information not required by the existing law or accounting standards (Dumontier and Raffournier, 1999 quoted by Ding et al., 2004). The link between corporate disclosure policy and analyst behaviour has also been investigated (Lang and Lundholm, 1996 quoted by Ding et al., 2004), as well as the relation between the disclosure level and the cost of equity capital (Botosan, 1997; Botosan and Plumlee, 2002 quoted by Ding et al., 2004).

Healy and Palepu (2001) discussed the role of auditors in the disclosure process. The authors stated that the fact that stock markets react to earnings announcements (Kothari, 2001 quoted by Healy and Palepu, 2001) suggests that overall the accounting information is seen as credible by the investors, but is not clear if the credibility arises from the assurance provided by the auditor or whether there are other sources that influence it. Within our study we also considered the auditor's type as a independent variable in order to test if the volume of disclosure about fair value measurements in the financial statements is influenced by this characteristic.

Research on the level of compliance with International Accounting Standards began to emerge around the 2000, showing, at that time, a relatively high degree of non-compliance (Cairns, 1999, El-Gazzara et al., 1999; Street et al., 1999 quoted by Fekete, 2008:296). Further studies 
focused on the study of several companies listed on stock exchanges, trying to identify whether there are significant differences between companies listed on a U.S. stock exchange and the companies not traded on such exchange. The results indicated a bigger general level of compliance in companies that were also listed on a stock exchange in the USA (Glaum and Street, 2003 quoted by Tiron and Ratiu, 2010:187). As Mustata (2008) also discusses, the capital market represents an important factor when considering companies' financial reporting practices. Street and Gray (2002, quoted by Fekete, Matiş and Lukacs, 2008) makes a more comprehensive study on a sample of 272 international companies, considering factors such as size of the entity, profitability, industry, notes, auditor type and country in order to determine what influences the level of compliance with IFRS.

\section{Research methodology}

In this paper we attempt to sketch a guide of best practices on disclosures about fair value measurements in financial statements. Thus, we examined the requirements of the two major accounting standard setters, IASB (IFRS) and FASB (U.S. GAAP). Given the fact that IFRS 13 Fair Value Measurement was developed in a joint project of the IASB and FASB, as part of the Memorandum of Understanding (MoU), and later also FASB issued Accounting Standards Update (ASU) No. 2011-04 Amendments to Achieve Common Fair Value Measurement and Disclosure Requirements in U.S. GAAP and IFRSs, fair value measurement and disclosure requirements are largely the same in the two sets of standards. The truth is that in this issue, the IASB has rather turned towards FASB's perspective. However this is not necessarily to blame given the long history of fair value in the U.S. accounting standards and hence the FASB's extensive experience in this area.

Following the above mentioned analysis being performed on accounting standards, we have selected the below presented required disclosures (which are included within IFRS 13 Fair Value Measurement) that were considered in developing our study due to their necessity in ensuring a better informing of the users of accounting information:

A. For recurring and non-recurring fair value measurements, the fair value measurement at the end of the reporting period. Recurring fair value measurements of assets or liabilities are those that other IFRSs require or permit in the statement of financial position at the end of each reporting period (IFRS 13, paragraph 93(a)).

B. For non-recurring fair value measurements, the reasons for the measurement). Nonrecurring fair value measurements of assets or liabilities are those that other IFRSs require or permit in the statement of financial position in particular circumstances ${ }^{4}$ (IFRS 13, paragraph 93(a)).

C. For recurring and non-recurring fair value measurements, the level of the fair value hierarchy within which the fair value measurements are categorised in their entirety (IFRS 13, paragraph 93(b)).

D. For assets and liabilities held at the end of the reporting period that are measured at fair value on a recurring basis, the amounts of any transfers between Level 1 and Level 2 of the fair value hierarchy, the reasons for those transfers and the entity's policy for determining when

\footnotetext{
${ }^{4}$ One of these situations is that when an entity measures an asset held for sale at fair value less costs to sell in accordance with IFRS 5 Non-current Assets Held for Sale and Discontinued Operations because the asset's fair value less costs to sell is lower than its carrying amount (IFRS 13, paragraph 93(b)).
} 
transfers between levels are deemed to have. Transfers into each level shall be disclosed and discussed separately from transfers out of each level (IFRS 13, paragraph 91(c)).

E. For recurring and non-recurring fair value measurements categorised within Level 2 and Level 3 of the fair value hierarchy, a description of the valuation technique(s) and the inputs used in the fair value measurement. If there has been a change in valuation technique (eg. changing from a market approach to an income approach or the use of an additional valuation technique), the entity shall disclose that change and the reason(s) for making it. For fair value measurements categorised within Level 3 of the fair value hierarchy, an entity shall provide quantitative information about the significant unobservable inputs used in the fair value measurement. An entity is not required to create quantitative information to comply with this disclosure requirement if quantitative unobservable inputs are not developed by the entity when measuring fair value (eg when an entity uses prices from prior transactions or third-party pricing information without adjustment). However, when providing this disclosure an entity cannot ignore quantitative unobservable inputs that are significant to the fair value measurement and are reasonably available to the entity (IFRS 13, paragraph 91(d)).

F. For recurring fair value measurements categorized within Level 3 of the fair value hierarchy, a reconciliation from the opening balances to the closing balances, disclosing separately changes during the period attributable to the following:

a. total gains or losses for the period recognised in profit or loss, and the line item(s) in profit or loss in which those gains or losses are recognised (IFRS 13, paragraph 91(e));

b. the amounts of any transfers into or out of Level 3 of the fair value hierarchy, the reasons for those transfers and the entity's policy for determining when transfers between levels are deemed to have occurred. Transfers into Level 3 shall be disclosed and discussed separately from transfers out of Level 3 (IFRS 13, paragraph 91(e)).

G. For recurring and non-recurring fair value measurements categorised within Level 3 of the fair value hierarchy, a description of the valuation processes used by the entity (IFRS 13, paragraph 91(g)).

H. For recurring fair value measurements categorised within Level 3 of the fair value hierarchy a narrative description of the sensitivity of the fair value measurement to changes in unobservable inputs if a change in those inputs to a different amount might result in a significantly higher or lower fair value measurement. If there are interrelationships between those inputs and other unobservable inputs used in the fair value measurement, an entity shall also provide a description of those interrelationships and of how they might magnify or mitigate the effect of changes in the unobservable inputs on the fair value measurement (IFRS 13, paragraph 91(h)).

I. An entity shall present the quantitative disclosures required by this IFRS in a tabular format unless another format is more appropriate (IFRS 13, paragraph 99).

Given the fact that the debate on the usefulness of fair value accounting was enhanced in connection with the financial crush and economic crisis of 2007-2009, when fair value accounting opponents have insisted that financial statements based on fair value measurements has accelerated the financial crisis and significantly worsened the impact on affected companies (Hughes \& Tett, 2008; King, 2009; Veron, 2008), we intend to analyze the extent to which the fair value disclosure requirements were fulfilled by the companies from financial sector and to identify the factors that influence the disclosures about fair value measurements. Therefore we selected 20 publicly traded companies from the financial sector. A total of 10 companies were selected from the constituents of 
the London Stock Exchange index FTSE 100. We selected the FTSE index because it represents the performance of the 100 largest blue chip ${ }^{5}$ companies listed on the London Stock Exchange, which have a total market capitalization that worth $81 \%$ of the UK stock market ${ }^{6}$. The other 10 companies were selected from the constituents of the Frankfurt ${ }^{7}$ Stock Exchange DAX and MDAX indices. These two indices were chosen because DAX is the index of the first 30 German blue chips and MDAX is the index of the following 50 companies of Frankfurt Stock Exchange, considering the criteria of market capitalization.

The two stock exchanges were selected based on a $\mathrm{FESE}^{8}$ report for the year 2012, report which states that the two stock exchanges have recorded the highest turnover, and London Stock Exchange is placed on the first position ${ }^{9}$. All the companies are selected from the financial sector because for the companies in this sector the percentage of assets measured at fair value is higher, which is why in the recent economic and financial crisis they have aroused the greatest controversy about the value of financial assets. Since we aimed to analyze how the volume of disclosures on fair value measurements was affected by the recent economic and financial crisis, we tried to find in the financial statements of the selected companies the best practice requirements set out earlier. Thus, for each company we investigated the financial statements of the years 2007, 2008 and 2009. We chose these financial years since the financial, monetary and banking crisis in 2008 that began as an issue of subprime lending in the United States in second quarter of 2008 spread rapidly in the third quarter in Western Europe and in the fourth quarter in Central and Eastern Europe. Therefore, we considered it appropriate to analyze the situation before the burst of the crisis (2007), the financial statements prepared in 2008 (the year in which the crisis spread to Europe) and the statements for 2009. Once we have identified or not this information in the financial statements, we determined the item sought, Disclosure Index based on the following formula:

$$
D_{I}=\frac{\sum_{i=1}^{m} d_{i}}{\sum_{i=1}^{n} d_{i}}, \text { unde } D_{I} \in[0,1]
$$

Where:

$D_{I}=$ Disclosure index,

$d_{i}=1$ if information was provided and 0 otherwise,

$m=$ number of items effectively disclosed,

$n=$ maximum number of disclosure items possible

\footnotetext{
${ }^{5}$ The term blue chip is a label used to describe a publicly recognized, well-established and financially sound company. Blue chips generally sell high-quality, widely accepted products and services. Blue chip companies are known to weather downturns and operate profitably in the face of adverse economic conditions, which helps to contribute to their long record of stable and reliable growth (http://www.investopedia.com/terms/b/bluechip.asp\#axzz2LpWyV7Ro accessed at 10.06.2012).

${ }^{6} \mathrm{http}: / / \mathrm{www} . \mathrm{ftse} . \mathrm{com} /$ Indices/UK_Indices/index.jsp accessed at 10.06.2012.

${ }^{7} \mathrm{http}: / /$ deutsche-boerse.com

${ }^{8}$ Federation of European Securities Exchange

${ }^{9}$ The report can be accessed at http://www.fese.be/en/?inc=art\&id=81.
} 
In order to determine DI for all selected companies we have used Microsoft Excel, and in this way we had accurate records of items that were been disclosed, as well as those that were omitted or were not applicable ( $\mathrm{n} / \mathrm{a}$ ). We classified pieces of information as inapplicable, in order not to distort Di by stating that a group did not have disclosed information that could not be shown. After determining the disclosure index for each company and reporting year, we selected the factors that potentially influenced the evolution of DI and made the appropriate statistical tests. The employed research methodology and applied model draws from similar studies being developed in research literature, as discussed in the literature review section.

\section{Potential determinants of disclosure practices and particularities in the context of European funding}

In this section we aim to identify factors that influence the value of fair value measurements disclosure index. Following the determination of the disclosure index, we tried to identify the factors that could have influence on it. We considered, therefore, the turnover of the company, auditor's type, country of origin of the company and industry. Companies that were listed on the London stock exchange had the turnover expressed in pounds sterling (GBP) or U.S. dollars, but they were converted into the euro (EUR), using the official course at 31.12.2007, 31.12.2008, respectively 31.12.2009 the dates for which the financial statements were prepared. When we refer to auditor's type we verified if the group was audited by an auditor belonging to the Big4 (Deloitte Touche Tohmatsu (USA); PricewaterhouseCoopers (UK); Ernst \& Young (UK); KPMG (Netherlands)) or another. To determine the relationship between these factors, considered independent variable, and DI considered the dependent factor, we used the statistical program SPSS.

The dependent variable is the disclosure index (DI), whose determination method was already described in this paper. We try to explain the variation in the index through factors taken from the literature in this field, namely:

$>$ The size of the entity, operationalized through the natural logarithm of turnover because we wanted to eliminate to some extent the effects of size (scale effects), which occur due to high dispersion of turnover in the sample;

$>$ Auditor's type, a dichotomous variable that takes value 1 if financial statements are audited by a Big4 audit firm and 0 otherwise;

$>$ Predominant economic sector in which the company operates. All variables representing industry: financial services, insurance and banking, take value 1 if the firm operates in the field and 0 otherwise;

$>$ The country in which the company is located (Germany, UK) is also a dichotomous variable.

Table no.1.

Descriptive statistics of the variables included in the statistical model

\begin{tabular}{|c|c|c|c|}
\hline & Mean & Std. Deviation & $\mathbf{N}$ \\
\hline DI2007 & .4983 & .19899 & 20 \\
\hline DI2008 & .5838 & .22406 & 20 \\
\hline DI2009 & .7100 & .21738 & 20 \\
\hline LNCA2007 & 8.1000 & 2.31471 & 20 \\
\hline
\end{tabular}




\begin{tabular}{|c|c|c|c|}
\hline LNCA2008 & 8.2000 & 2.23842 & 20 \\
\hline LNCA2009 & 8.2000 & 2.26181 & 20 \\
\hline GERM & .5000 & .51299 & 20 \\
\hline UK & .5000 & .51299 & 20 \\
\hline FINANCIAL & .4000 & .50262 & 20 \\
\hline INSURANCE & .2500 & .44426 & 20 \\
\hline Banks & .3500 & .48936 & 20 \\
\hline TIP_AUD & .9500 & .22361 & 20 \\
\hline \multicolumn{4}{|c|}{ Source: authors' computation } \\
\hline
\end{tabular}

All variables which we want to include in the statistical model are shown in the table above and described by the mean and standard deviation. The table also indicates that we don't have omitted variables. For DI and turnover there are available data for each of the three years analyzed. We notice, based on the table that the average DI in 2007 is 0.4983 , but increased in 2009 to 0.7100. Disclosure index mean deviates from the average with 0.19899 in 2007, with 0.22406 in 2008 and 0.21738 in 2009. Studied sample consists of 20 companies. follows:

The general form of the model that includes all the proposed variables was computed as

$\mathrm{DI}=\mathrm{a}_{1}+\mathrm{a}_{2} \mathrm{LNCA}+\mathrm{a}_{3}$ TIP_AUD $+\mathrm{a}_{4}+\mathrm{a}_{5}$ FINANCIAL $+\mathrm{a}_{6}$ INSURANCE $+\mathrm{a}_{7}$ BANKS $+\mathrm{a}_{8} \mathrm{GERM}$ $+\mathrm{a}_{9} \mathrm{~GB}+\varepsilon$

Where:

DI - disclosure index; CA - turnover; TIP_AUD - auditor's type;

Variables FINANCIAL, INSURANCE, BANKS represent industry and take the value 1 if the entity operates predominantly in the sector and 0 otherwise.

GERM and GB variables refers to the country in which the group has its headquarters and are also dichotomous variables that take the value 1 if the entity is situated in that country and 0 otherwise. below:

Developing the analysis and interpreting results was done by following the hypotheses

H1: Company size influences the level of compliance with the disclosure requirements for fair value measurements in the financial statements, we believe that a truly great and hence a vast market exposure will be interested to maintain investor interest by providing accounting information quality. In addition, previous studies (Fekete et. al, 2008) confirmed this hypothesis.

H2: Auditor's type influences the level of compliance with the disclosure requirements for fair value measurements in the financial statements, we believe that if the company's financial statements are audited by an audit firm from Big4 group, characterized by high professionalism, will strive to achieve the highest possible degree of compliance with accounting standards.

H3: Sector influences the level of compliance with the disclosure requirements for fair value measurements in the financial statements, we expect the specific activity to influence the 
level of compliance with the disclosure requirements for fair value given the high percentage of financial assets measured at fair value in the financial statements, together with the ongoing battle of the big banking groups to meet capital requirements.

H4: Country in which the group is located influences the level of compliance with the disclosure requirements for fair value measurements in the financial statements, we expect the level of compliance to be influenced by the state where the company is based, taking into account the differences between the considered two countries (Germany and UK). Germany is a landlocked country, while Britain is an island country, part of Anglo-Saxon, with different rules and principles, sometimes rather close to those of the U.S.

In order to verify the assumptions being made and to determine if the potential identified factors really influence the size of DI, we test the above proposed model. This test shall be performed on data for each year considered.

Testing the model for 2007 data

The following table contains the variables that we want to introduce in the model, with the indication that the dependent variable is the Disclosure index.

Variables Included/Removed(b) into/from the model

\begin{tabular}{|c|c|c|c|}
\hline Model & Variables Entered & $\begin{array}{c}\text { Variables } \\
\text { Removed }\end{array}$ & Method \\
\hline \multirow{3}{*}{1} & $\begin{array}{c}\text { TIP_AUD, } \\
\text { INSURANCE, UK, } \\
\text { LNCA2007, } \\
\text { Banks(a) }\end{array}$ & $\cdot$ & Enter \\
\hline
\end{tabular}

a Tolerance $=.000$ limits reached, b Dependent Variable: DI2007

Source: authors' computation

Analyzing the Model Summary table we would be tempted to say that DI is determined on in proportion of $23.6 \%$ by the selected factors.

Model Summary for 2007

\begin{tabular}{|c|c|c|c|c|}
\hline Model & R & R Square & $\begin{array}{c}\text { Adjusted R } \\
\text { Square }\end{array}$ & $\begin{array}{c}\text { Std. Error of the } \\
\text { Estimate }\end{array}$ \\
\hline 1 & $.661(\mathrm{a})$ & .437 & .236 & .17398 \\
\hline
\end{tabular}

a Predictors: (Constant), TIP_AUD, INSURANCE, UK, LNCA2007, Banks

Source: authors' computation

However, if we turn our attention towards the ANOVA test including test of significance for $\mathrm{R}$, we see that Sig. $=0.116$. Since Sig. is higher than the threshold of 0.05 , we decide the acceptance the null hypothesis and reject the hypothesis of a significant relationship between DI and factors considered in the model. 
$\operatorname{ANOVA(b)~for~} 2007$ data

\begin{tabular}{|c|c|c|c|c|c|c|}
\hline \multirow{2}{*}{ Model } & & $\begin{array}{c}\text { Sum of } \\
\text { Squares }\end{array}$ & df & $\begin{array}{c}\text { Mean } \\
\text { Square }\end{array}$ & F & Sig. \\
\hline \multirow{3}{*}{1} & Regression & .329 & 5 & .066 & 2.171 & $.116(\mathrm{a})$ \\
\cline { 2 - 7 } & Residual & .424 & 14 & .030 & & \\
\cline { 2 - 7 } & Total & .752 & 19 & & & \\
\hline
\end{tabular}

a Predictors: (Constant), TIP_AUD, INSURANCE, UK, LNCA2007, Banks

b Dependent Variable: DI2007

Source: authors' computation

So all four hypotheses considered at the beginning of the testing are rejected.

Testing the model for 2008 data

The following table contains the variables that we want to introduce in the model, with the indication that the dependent variable is the Disclosure index.

Variables Included/Removed(b) into/from the model

\begin{tabular}{|c|c|c|c|}
\hline Model & Variables Entered & Variables Removed & Method \\
\hline \multirow{2}{*}{1} & $\begin{array}{c}\text { TIP_AUD, } \\
\text { INSURANCE, UK, } \\
\text { LNCA2008, Banks(a) }\end{array}$ & $\cdot$ & Enter \\
\hline
\end{tabular}

a Tolerance $=.000$ limits reached. b Dependent Variable: DI2008

Source: authors' computation

Analyzing the Model Summary table we would be tempted to say that DI is determined on in proportion of $23.3 \%$ by the selected factors.

Model Summary for 2008

\begin{tabular}{|c|c|c|c|c|}
\hline Model & R & R Square & $\begin{array}{c}\text { Adjusted R } \\
\text { Square }\end{array}$ & $\begin{array}{c}\text { Std. Error of the } \\
\text { Estimate }\end{array}$ \\
\hline 1 & $.660(\mathrm{a})$ & .435 & .233 & .19618 \\
\hline
\end{tabular}

a Predictors: (Constant), TIP_AUD, INSURANCE, UK, LNCA2008, Banks

Source: authors' computation

However, if we turn our attention towards the ANOVA test including test of significance for $\mathrm{R}$, we see that Sig. $=0.118$. Since Sig. is higher than the threshold of 0.05 , we decide the acceptance the null hypothesis and reject the hypothesis of a significant relationship between DI and factors considered in the model. 
$\operatorname{ANOVA}(b)$ for 2008 data

\begin{tabular}{|c|c|c|c|c|c|c|}
\hline Model & & $\begin{array}{c}\text { Sum of } \\
\text { Squares }\end{array}$ & df & Mean Square & F & Sig. \\
\hline \multirow{3}{*}{1} & Regression & .415 & 5 & .083 & 2.157 & $.118(\mathrm{a})$ \\
\cline { 2 - 7 } & Residual & .539 & 14 & .038 & & \\
\cline { 2 - 7 } & Total & .954 & 19 & & & \\
\hline
\end{tabular}

a Predictors: (Constant), TIP_AUD, INSURANCE, UK, LNCA2008, Banks

b Dependent Variable: DI2008

Source: authors' computation

So all four hypotheses considered at the beginning the research are rejected.

Testing the model for 2009 data

Analyzing the output generated by SPSS, we see that DI for financial statements of 2009 is influenced in a proportion of $37.8 \%$ by the factors considered, except FINANCIAL and GERM variables that were excluded from the model. In ANOVA analysis, we find that Sig. $=0.035<0.05$, which leads to acceptance of the hypothesis that the size of the entity, type of auditor and certain sectors significantly influence DI.

Table no. 8 .

Model Summary for 2009

\begin{tabular}{|c|c|c|c|c|}
\hline Model & R & R Square & $\begin{array}{c}\text { Adjusted R } \\
\text { Square }\end{array}$ & $\begin{array}{c}\text { Std. Error of the } \\
\text { Estimate }\end{array}$ \\
\hline 1 & $.736(\mathrm{a})$ & .542 & .378 & .17142 \\
\hline
\end{tabular}

a Predictors: (Constant), TIP_AUD, INSURANCE, UK, LNCA2009, Banks

Source: authors' computation

Table no. 9 .

$\operatorname{ANOVA}(b)$ for 2009 data

\begin{tabular}{|c|c|c|c|c|c|c|}
\hline \multirow{2}{*}{ Model } & & $\begin{array}{c}\text { Sum of } \\
\text { Squares }\end{array}$ & df & $\begin{array}{c}\text { Mean } \\
\text { Square }\end{array}$ & F & Sig. \\
\hline \multirow{3}{*}{1} & Regression & .486 & 5 & .097 & 3.311 & $.035(\mathrm{a})$ \\
\cline { 2 - 7 } & Residual & .411 & 14 & .029 & & \\
\cline { 2 - 7 } & Total & .898 & 19 & & & \\
\hline
\end{tabular}

a Predictors: (Constant), TIP_AUD, INSURANCE, UK, LNCA2009, Banks

b Dependent Variable: DI2009

Source: authors' computation

In this situation, the next step is to analyze the table that contains the coefficients B and select those variables whose coefficients are significant. If Sig. for each coefficient is lower than the threshold of 0.1, the coefficients are significant and related variables should be kept in the model. Otherwise, we have to eliminate those variables from the equation. If we accept were accepted the assumption of a significant relationship between DI and factors considered, we would have included just LNCA2009 variable in the model because for only this Sig. $<0.1$. 
Model coefficients(a) for 2009

\begin{tabular}{|c|c|c|c|c|c|c|}
\hline \multirow{3}{*}{ Model } & \multicolumn{2}{|c|}{$\begin{array}{c}\text { Unstandardized } \\
\text { Coefficients }\end{array}$} & $\begin{array}{c}\text { Standardized } \\
\text { Coefficients }\end{array}$ & $\mathbf{t}$ & Sig. \\
\cline { 3 - 7 } & & $\mathbf{B}$ & $\begin{array}{c}\text { Std. } \\
\text { Error }\end{array}$ & Beta & $\mathbf{B}$ & $\begin{array}{c}\text { Std. } \\
\text { Error }\end{array}$ \\
\hline \multirow{4}{*}{1} & (Constant) & .323 & .210 & & 1.543 & .145 \\
\cline { 2 - 7 } & LNCA2009 & .045 & .024 & .472 & 1.879 & .081 \\
\cline { 2 - 7 } & UK & .034 & .080 & .081 & .431 & .673 \\
\cline { 2 - 7 } & INSURANCE & .078 & .122 & .159 & .638 & .534 \\
\cline { 2 - 7 } & Banks & .185 & .115 & .416 & 1.612 & .129 \\
\cline { 2 - 7 } & TIP_AUD & -.091 & .193 & -.093 & -.471 & .645 \\
\hline
\end{tabular}

a Dependent Variable: DI2009

Source: authors' computation

In this situation, we decided to analyze separately the influence of LNCA2009 on the disclosure index.

Table no.11.

Model Summary for the variable LNCA2009

\begin{tabular}{|c|c|c|c|c|}
\hline Model & $\mathbf{R}$ & R Square & $\begin{array}{c}\text { Adjusted R } \\
\text { Square }\end{array}$ & $\begin{array}{c}\text { Std. Error of the } \\
\text { Estimate }\end{array}$ \\
\hline 1 & $.660(\mathrm{a})$ & .436 & .405 & .16769 \\
\hline
\end{tabular}

a Predictors: (Constant), LNCA2009

Source: authors' computation

Table no. 12.

ANOVA analysis for variable LNCA2009

\begin{tabular}{|c|c|c|c|c|c|c|}
\hline \multirow{2}{*}{ Model } & & $\begin{array}{c}\text { Sum of } \\
\text { Squares }\end{array}$ & df & Mean Square & F & Sig. \\
\hline \multirow{3}{*}{1} & Regression & .392 & 1 & .392 & 13.928 & $.002(\mathrm{a})$ \\
\cline { 2 - 7 } & Residual & .506 & 18 & .028 & & \\
\cline { 2 - 7 } & Total & .898 & 19 & & & \\
\hline
\end{tabular}

a Predictors: (Constant), LNCA2009 b Dependent Variable: DI2009

Source: authors' computation

Table no. 13.

Model coefficients(a) for LNCA2009

\begin{tabular}{|c|c|c|c|c|c|c|c|c|c|}
\hline \multirow{2}{*}{ Model } & & \multicolumn{2}{|c|}{$\begin{array}{c}\text { Unstandardized } \\
\text { Coefficients }\end{array}$} & $\begin{array}{c}\text { Standardized } \\
\text { Coefficients }\end{array}$ & \multicolumn{1}{|c|}{ S } & \multicolumn{2}{|c|}{ Sig. } & \multicolumn{2}{|c|}{ Correlations } \\
\cline { 3 - 10 } & & B & Std. Error & Beta & $\begin{array}{c}\text { Zero- } \\
\text { order }\end{array}$ & Partial & Part & B & $\begin{array}{c}\text { Std. } \\
\text { Error }\end{array}$ \\
\hline \multirow{2}{*}{1} & (Constant) & .189 & .144 & & 1.312 & .206 & & & \\
\cline { 2 - 11 } & LNCA2009 & .063 & .017 & .660 & 3.732 & .002 & .660 & .660 & .660 \\
\hline
\end{tabular}

a Dependent Variable: DI2009

Source: authors' computation 
Analyzing the output generated by SPSS, we see that DI for 2009 financial statements is influenced in a proportion of $40.5 \%$ by the turnover of the company. Also note that Sig. $=0.002<0.05$, which leads to acceptance of the hypothesis that the entity's significantly affect DI. Therefore, for 2009 financial statements, the proposed model equation is:

$$
\text { DI2009 }=0.189+0.063 \text { LNCA2009 }+\varepsilon
$$

Another aspect which was followed throughout the developed analysis is closely linked to particularities regarding fair value measurement related disclosures in the context of European funding (subsidies) and other assistance. The information collected from companies' financial statements mainly emphasize that subsidies, including non-monetary subsidies at fair value, should only be recognised when there is reasonable assurance that the entity will comply with any conditions attached to them and the subsidy will be received (as also stipulated by IAS 20). While recording both the asset and the subsidy at a nominal amount is also permitted, IAS 20 mentions non-monetary subsidies usually being accounted for at fair value. Since IAS 20 requires subsidies to be recognised in profit or loss on a systematic basis over the periods in which the entity recognises expenses for the related costs for which the subsidies are intended to compensate, the fair value measurement impacts not only initial recognition, but also subsequent financial reporting periods. With these particularities in mind, fair value measurement disclosure practices also become significant when it comes to obtaining European funding (subsidies) and other assistance. We will further synthesize the main conclusions that can be drawn based on the analysis which we developed on a sample of companies getting their financing from two main European capital markets.

\section{Conclusions, limitations and future research}

In this paper we addressed the issue of fair value measurement disclosure in the financial statements. Thus, we selected a sample of 20 companies listed on the London Stock Exchange and Frankfurt Stock Exchange. All the companies selected are activating in the financial sector. We analyzed the financial statements of these companies for the years 2007, 2008 and 2009 to identify the extent to which they provide information related to fair value. Following the analysis performed we attempted to determine whether the disclosure index value is influenced by factors such as the size of the company, entity's financial statements auditor type, sector of activity or the country in which is located.

Based on regressions performed in SPSS we determined that the entity size positively affect the fair value measurements disclosure index. This result was expected, given the results of previous empirical studies, however for an accurate analysis of this issue we recommend selecting a larger sample and effectuating the analysis of financial statements corresponding to several financial years. The main limitation of the study is one typical to empirical studies, namely the sample and data quality in general. Due limited possibilities samples used in empirical studies are of relatively small volume (in this case 20 statistical units). This obviously affects the accuracy of the results, but I believe that does not affect the validity of the conclusions drawn in this study. Regarding prospects for future research, specifically, starting from this case study, the following improvements are needed: expanding the sample to a larger number of companies, especially comprising also companies listed on stock exchanges from USA, in order to capture differences in 
the application of rules-based standards (U.S. GAAP) and those based on principles (IFRS ); identifying and use of other factors in explaining phenomena, especially among those related to corporate governance; expanding the study over a larger period of time to assess the dynamics of financial reporting.

\section{Acknowledgement}

This paper is one of the research outputs of the project POSDRU/86/1.2/S/64076 „Adaptarea curriculei universitare, de masterat, la cerințele pieței muncii din România în domeniul proiectelor finanţate din fondurile structurale şi de coeziune".

\section{References}

1. Botosan C. A., 1997. Disclosure level and the cost of equity capital, The Accounting Review, 72(3, July), pp.323-349

2. Botosan C. A., Plumlee M. A., 2002. A re-examination of disclosure level and the expected cost of equity capital, Journal of Accounting Research, 40 (1, March), pp. 21-40

3. Core J. E., 2001. A review of the empirical disclosure literature: Discussion, Journal of Accounting and Economics, 31, pp. 441-456;

4. Cairns D., 1999. The FT International Accounting Standards Survey, London, Financial Times

5. Ding Y., Fu L., Stolowy H., Wang H., 2004. Disclosure and determinants studies: An extension with the divisive clustering method (DIV), International Conference on Research Methods "CROSSING FRONTIERS IN QUANTITATIVE AND QUALITATIVE RESEARCH METHODS", March 18-20, 2004, Lyon, France

6. Dumontier P., Raffournier B., 1999. Vingt ans de recherche positive en comptabilité financière, Comptabilité Contrôle Audit, Numéro spécial (Les vingt ans de l'AFC), pp. 179197

7. El-Gazzar S.M., Finn Ph.M., Jacob R., 1999. An Empirical Investigation of Multinational Firms' Compliance with International Accounting Standards, International Journal of Accounting, 34(2), pp. 239-48

8. Fekete S., 2009. Cercetare conceptuală şi empirică privind raportările financiare din România şi Ungaria, Casa Cărții de Ştiință Publishing House, Cluj Napoca

9. Fekete S., Matiş D., Lukacs J., 2008. Factors Influencing the Extent of Corporate Compliance with IFRS The Case of Hungarian Listed Companies, Annales Universitatis Apulensis series Oeconomica, 10 (1), pp. 46-57

10. Financial Accounting Standards Board, 2011. Accounting Standards Update (ASU) No. 2011-04 Amendments to Achieve Common Fair Value Measurement and Disclosure Requirements in U.S. GAAP and IFRSs

11. Glaum M., Street D.L., 2003. Compliance with the Disclosure Requirements of Germany's New Market: IAS Versus US GAAP, Journal of International Financial Management and Accounting, Vol. 14, pp. 64-100

12. Healy P. M., Palepu K. G., 2001. Information asymmetry, corporate disclosure, and the capital markets: A review of the empirical disclosure literature, Journal of Accounting and Economics, 31, pp. 405-440 
13. Hughes J., Tett G., 2008. An unforgiving eye: bankers cry foul over fair value accounting, Financial Times, 14 March

14. International Accounting Standards Board, 2011. IFRS 13 Fair Value Measurement, May 2011

15. International Accounting Standards Board, 2008. IAS 20 Accounting for Government Grants and Disclosure of Government Assistance, revised May 2008

16. King A.M., 2009. Determining fair value, Strategic Finance, vol. 1, pp. 27-32

17. Kothari S.P., 2001. Capital markets research in accounting, Journal of Accounting and Economics, vol. 31, pp. 105-231

18. Lang M. H., Lundholm R. J., 1996. Corporate disclosure policy and analyst behavior, The Accounting Review, 71(4), pp. 467-492

19. Mustata R.V., 2008. Sisteme de masurare a armonizarii si diversitatii contabile - intre necessitate si spontaneitate, Casa Cartii de Stiinta Publishing House, Cluj Napoca

20. Street D.L., Gray S.J., 2002. Factors influencing the extent of corporate compliance with International Accounting Standards: summary of a research monograph, Journal of International Accounting, Auditing and Taxation, 11, pp. 51-76

21. Street D.L., Gray S.J., Bryant S.M., 1999. Acceptance and Observance of International Accounting Standards: An empirical study of companies claiming to comply with IASs, The International Journal of Accounting, 34 (1), pp. 11-48

22. Tiron-Tudor A., Rațiu R.V., 2010. How transparent are companies listed on the Bucharest Stock Exchange when disclose them consolidated financial statements?, Annales Universitatis Apulensis Series Oeconomica, 12(1), pp. 185-190

23. Veron N., 2008. Fair Value Accounting is the Wrong Scapegoat for this Crisis, Accounting in Europe, vol. 5, no. 2, pp. 63-69 